\title{
FILOSOFI RITUAL HINDU, PERGESERAN ANTARA KONSEP DAN KONTEKS
}

\author{
Oleh: \\ I Gusti Ketut Widana \\ igustiketutwidana1805@gmail.com \\ Universitas Hindu Indonesia \\ Denpasar
}

Proses Review 28 Agustus-1 Oktober, Dinyatakan Lolos 4 Oktober

\begin{abstract}
His remains are an (absolute) obligation for Hindus. The basis of Hindu theology is that the world and all its contents were created by God (Prajapati) through his yad. So as one form of devotion to Hindus before God is to carry out yadnya. Actually there are several definitions of yadnya, including sacrifice, giving, devotion, service, but what is commonly understood and practiced by Hindus is in the form of ritual. The ritual activity itself is packaged in the implementation of a ceremony complete with its upakara bebanten facilities (offerings). Up to this point, his understanding had narrowed in meaning, as if it were limited or limited to mere ritual activities. Then there is a shift between concepts in the context of their implementation, where the philosophy of the majority tends to develop more towards the materialization of the ideas of God, compared to the transcendence towards strengthening the attitude and behavior of God.
\end{abstract}

Keywords: ritual philosophy, concepts, context

\begin{abstract}
Abstrak
Mayadnya adalah kewajiban (mutlak) bagi umat Hindu. Landasan teologi Hindu mendoktrin bahwa dunia beserta segenap isinya diciptakan Tuhan (Prajapati) melalui yadnya. Sehingga sebagai salah satu wujud bhakti umat Hindu kehadapan Tuhan adalah dengan melaksanakan yadnya. Sebenarnya ada beberapa pengertian yadnya, di antaranya pengorbanan, pemberian, pengabdian, pelayanan, namun yang lumrah dipahami dan dilaksanakan umat Hindu adalah dalam bentuk ritual. Aktivitas ritual itu sendiri dikemas dalam pelaksanaan upacara lengkap dengan sarana upakara bebantennya (sesaji). Sampai pada titik ini, pengertian yadnya mengalami penyempitan makna, seolah sebatas atau terbatas pada kegiatan ritual semata. Terjadi kemudian pergeseran antara konsep dalam konteks pelaksanaannya, dimana filosofi mayadnya cenderung berkembang lebih ke arah materialisasi ide-ide ketuhanan, dibandingkan dengan transendensi ke arah penguatan sikap dan perilaku berketuhanannya.
\end{abstract}

Kata Kunci: filosofi ritual, konsep, konteks 


\section{PENDAHULUAN}

Beranjak dari landasan teologis yang melahirkan suatu keyakinan (sradha), maka dalam merealisasikan bhakti, umat Hindu antara lain melakukan aktivitas ritual (yadnya). Pelaksanaan aktivitas ritual yadnya ini tidak lepas juga dari landasan filosofis. Landasan filosofis ini juga berdasarkan keyakinan (sradha) yang memberikan pengetahuan atau pemahaman bahwa keberadaan dunia beserta segala isinya ini diciptakan Ida Sanghyang Widhi Wasa/Tuhan Yang Maha Kuasa sebagaimana disuratkan di dalam kitab Bhagawadgita, III.10 : "Sahayajnah prajah srishtva, paro vacha pajapatih, anema prasavish dhvam, esha yostvisha kamaduk"

\section{Maknanya :}

'Pada zaman dulu kala Prajapati (Tuhan Yang Maha Esa) menciptakan manusia dengan Yadnya dan bersabda. Dengan ini engkau akan mengembang dan akan menjadi kamanduk (memenuhi) dari keinginanmu)' (Pudja, 1981: 76).

Secara substantif, kutipan sloka di atas menjelaskan, bahwa pelaksanaan yadnya dilandasi keyakinan bahwa Tuhan menciptakan dunia beserta segenap isinya berdasarkan yadnya. Atas dasar keyakinan itu terbangun pemahaman filosofis (konseptual) bahwa keberlangsungan kehidupan di dunia hanya akan dapat terjaga jika umat Hindu selaku hamba ciptaan-Nya melakukan yadnya. Hanya dengan saling beryadnya kehidupan di dunia ini dapat terus berlanjut (Cudamani, 1993 : 57). Keyakinan inilah kemudian melahirkan adanya perasaan berhutang (Rna) yang secara moral batiniah wajib dibayar, sebagai realisasi bhakti umat kepada Hyang Widhi/Tuhan, para Rsi dan juga Pitara.

\section{METODE DAN PEMBAHASAN}

Studi ini lebih kepada mengkomparasikan antara konsep yang didapatkan melalui teksteks agama dan konteks di lapangan. Sumber referensi yang digunakan adalah teks-teks agama, sloka-sloka dan fenomena yang terjadi di lapangan. Kedua sumber ini diolah dan dianalisis secara deskriptif kualitatif.

\subsection{Realisasi Rna dalam Yadnya}

Adanya ajaran yang kemudian melahirkan kesadaran berhutang (Rna) itu selanjutnya menjadi landasan filosofis pelaksanaan yadnya dalam bentuk ritual. Itulah sebabnya menurut Putra (1982: 2-3) umat Hindu memandang utama sekali kewajiban mayadnya, sehingga secara intrinsik berlandaskan keyakinan (sradha) umat Hindu menjadikan ritual yadnya sebagai epicentrum kegiatan keagamaannya. Kesemua itu dilakukan sebagai bentuk "pembayaran" (Bahasa Bali : mepenauran) atas hutang (Tri Rna) yang secara siklus akan dilakukan sepanjang hidupnya melalui aktivitas ritual yadnya yang secara garis besar dikelompokkan menjadi Panca Yadnya, dengan rincian :

a) Dewa Rna, yaitu hutang kehadapan Ida Sanghyang Widhi Wasa (Tuhan Yang Maha Esa) selaku Sang Pencipta dunia beserta segenap makhluknya yang dapat 'dibayar' dengan melaksanakan upacara Dewa Yadnya dan Bhuta Yadnya.

b) Rsi Rna, adalah hutang kepada orangorang suci seperti Maha Resi yang telah menerima dan kemudian menyiarkan atau menyebarkan wahyu atau ajaran Tuhan sebagai pedoman bagi kehidupan umat. Hutang kepada para Resi ini dapat 'dibayar' dengan melaksanakan upacara Rsi Yadnya.

c) Pitra Rna, tidak lain dari hutang kepada para leluhur, termasuk para orang tua yang karena jasa-jasa beliau menyebabkan kita semuanya dapat hadir (terlahir) ke dunia (mercapada), lalu dirawat hingga tumbuh berkembang sebagai manusia berguna. Pitra Rna ini dapat 'dibayar' dengan melaksanaan upacara Pitra Yadnya dan juga Manusa Yadnya.

Selanjutnya Subagiasta (2006: 83) menambahkan, bahwa secara filosofis, realisasi Tri Rna dalam bentuk Panca Yadnya memiliki makna sebagai berikut : 
a) Dewa Yadnya, adalah persembahan yang tulus ikhlas dan tanpa pamrih kehadapan Ida Sanghyang Widhi Wasa (Tuhan Yang Maha Esa) beserta manifestasi-Nya. Tujuan upacara Dewa Yadnya adalah untuk menyatakan rasa terima kasih kepada Tuhan atas kuasanya yang telah menjadikan segenap makhluk terutama manusia dengan segala berkah kehidupannya.

b) Manusa Yadnya, adalah persembahan yang tulus ikhlas dan tanpa pamrih kepada sesama manusia. Tujuannya untuk penyucian, baik secara lahir maupun batin. Bentuk ritualnya antara lain, mulai dari upacara dalam kandungan (magedong-gedongan), kelahiran, pemberian nama, tigabulanan (nyambutin), enambulanan (otonan), menek kelih, potong gigi (mesangih), hingga upacara perkawinan (pawiwahan).

c) Rsi Yadnya, adalah upacara persembahan tulus ikhlas dan tanpa pamrih yang dihaturkan kepada orang suci Hindu. Upacara ini bertujuan untuk menghormati para pandita, seperti upacara Diksa Pariksa atau upacara Dwijati.

d) Bhuta Yadnya, adalah pengorbanan suci kepada semua makhluk yang kelihatan maupun tidak kelihatan dan kepada alam semesta untuk memperkuat keharmonisan hidup. Contoh upacaranya antara lain : masegeh, macaru, dan tawur.

5) Pitra Yadnya, adalah persembahan yang dilandasi kesucian yang dihaturkan kepada Sang Pitara. Tujuannya adalah untuk memberikan persembahan kepada leluhur, menyelamatkan orangtua/ leluhur, bermaksud mengembalikan unsur Panca Maha Bhuta (pertiwi, apah, teja, bayu, akasa). Jenis upacara Pitra Yadnya diantaranya: upacara Ngaben, Upacara Sawa Wedana, Upacara Asti Wedana, Upacara Swasta, Upacara Nglungah, dan Upacara Atma Wedana.

\subsection{Sumber Filosofi Yadnya}

Yadnya secara mendasar adalah bagian dari
Sradha (keyakinan/keimanan) umat Hindu. Secara etimologi kata yadnya (yajna) berasal dari bahasa Sanskerta yaitu akar kata "yaj" yang artinya memuja, mempersembahkan, berkorban. Yadnya berarti pemujaan, persembahan, atau korban suci. Yajus berarti aturan tentang yadnya. Tentang Yadnya ini, pustaka Wraspati Tattwa menyatakan "Yadnya ngaraning manghanaken homa" (yadnya artinya mengadakan homa). Sementara itu dalam kitab Agastya Parwa disuratkan "Yadnya ngaranya "agnihotradi" kapujan sang hyang Siwagni pinakadinya (Yadnya artinya "agnihotra" yang utama yaitu pemujaan atau persembahan kepada Sang Hyang Siwa Agni). Intinya, yadnya itu adalah segala bentuk pemujaan atau persembahan dan pengorbanan yang tulus ikhlas yang timbul dari hati yang suci demi maksud-maksud mulia dan luhur (Titib, 2003: 103).

Adapun landasan filosofis pelaksanaan ritual yadnya, antara lain seperti dinyatakan di dalam kitab $\mathrm{Rg}$ Veda Mandala 1 bagian kelima Sukta 18.23 .8 : "dia membahagiakan sajian, dia meningkatkan upacara korban, suara pujaan kami sampai kepada Tuhan". Kemudian kitab Brahmana Purana, 20 menyebutkan "tujuh kesadaran yang diberikan oleh Hyang Citta kepada makhluk yaitu tidak tamak, memberi, kesetiaan, kebenaran, ilmu pengetahuan, kesadaran, dan yadnya. Selanjutnya kitab Manawadharmasastra, I.22 menegaskan : "Karmatmanam ca devanam, so srjatpraninam prabhuh, sadhyanam ca gunam suksmam, yajnam caiva sanatanam" (Tuhan yang menciptakan tingkatan-tingkatan dari pada dewa-dewa yang memiliki hidup dan mempunyai sifat bergerak, juga diciptakan tingkat sadhya yang berbadan halus serta upacara-upacara yang kekal) (Pudja dan Sudharta, 1977/1978: 217).

Selain petikan pustaka suci diatas, kitab Manawadharmasastra, IV.21 juga menyuratkan tentang kewajiban umat Hindu yang tidak boleh dilupakan dalam mayadnya :

"Rsi yajnam dewa yajnam bhuta yajnam ca sarwada,

Nryajnam pitra yajnam ca yatha sakti na hapayet" 


\section{Maknanya :}

'Hendaknya jangan sampai lupa, jika mampu laksanakanlah rsi yadnya, dewa yadnya, bhuta yadnya, manusa yadnya dan pitra yadnya' (Pudja dan Sudharta, 1977/1978: 136).

Berikutnya, kitab Bhagawadgita melalui beberapa adhyaya dan slokanya, baik secara tersurat maupun tersirat juga mengemukakan tentang landasan filosofis pelaksanaan yadnya agar apa yang dicita-citakan dapat mencapai hasil yang kesemuanya itu berasal dari Tuhan. Petikan Bhagawadgita, VII. 22 dimaksud berbunyi :

"Sa taya sraddhaya yuktas, tasyaradhanam ihate, labhate ca tatah Kaman, mayai wa wihitan hi tan"

\section{Maknanya :}

'Diberkahi dengan kepercayaan itu dia mencari penyembahan pada itu dan pula dia dapat apa yang dicita-citakan dan hasil mana adalah pemberian dari aku sendiri' (Pudja, 1981: 181)

Penegasan tentang apa makna ritual yadnya yang sesungguhnya berasal dari Tuhan itu kembali dinyatakan di dalam sloka Bhagawadgita, IX-16:

"Aham kratur aham yajnah swadha 'ham aham ausadham mantro 'ham aham ewajyam aham agnir aham hutam"

\section{Maknanya :}

'Aku adalah kegiatan ritual dan upacara kurban; Aku adalah persembahan leluhur dan reramuan obat-obatan; Aku adalah ucapan suci dan keju cair (reramuan persembahan api); Aku adalah api dan juga persembahan' (Pudja, 1981: 214)

Selain itu, yadnya yang dilaksanakan umat Hindu tidak boleh juga hanya sekedar apalagi dilakukan sembarangan, semuanya harus dilandasi perasaan hati yang tulus ikhlas sebagai kewajiban suci yang bersumber dari petunjuk kitab suci. Hal ini disuratkan di dalam kitab
Bhagavad Gita, XVII.11

"Aphalakaanksibhir yadnyo

vidhi drsto ya ijyate

yastavyam eveti manah

samaadaya sa saatvikah"

\section{Maknanya :}

'Yadnya yang dilakukan menurut petunjuk kitab suci (widhi drstah), dilakukan dengan ikhlas, yang sepenuhnya dipercaya bahwa yadnya itu sebagai suatu kewajiban suci. Yadnya yang demikian itu tergolong Satwika Yadnya'(Pudja, 1981: 364).

Sedangkan menyangkut unsur-unsur material persembahan yang dihaturkan, di dalam kitab Bhagawadgita, IX.26 diberikan rinciannya, yaitu :

"Patram puspam phalam toyam

yo me bhaktya prayacchati

tad aham bhakty-upahrtam

asnami prayatatmanah"

\section{Maknanya :}

'Siapapun yang mempersembahkan kepada-Ku dengan penuh pengabdian selembar daun, setangkai bunga, sebutir buah ataupun setetes air. Aku terima persembahan yang dilandasi kasih sayang dan hati yang murni itu' (Pudja, 1981: 220)

Pustaka tinggalan leluhur berupa lontar, dalam hal ini Lontar Tatwa Kusuma Dewa juga memberikan penguatan tentang pahala yang diperoleh jika melaksanakan yadnya. Petikan teksnya berbunyi :

"Rahayu pahalaya yan mangkana, sadadyani kaya olih sadya kaduluran Whidi, haywa enam ngutpati Dewa astiti ring Sang Hyang Widhi".

\section{Maknanya :}

'Selamat phalanya bila telah demikian seluruh sanak keluarga memperoleh penghasilan dikarunia Tuhan. Janganlah ragu-ragu beryadnya pada Dewa dan berbakti Pada Tuhan'. 
Berpijak pada kutipan beberapa teks pustaka suci diatas, dapat dipahami bahwa secara filosofis pelaksanan aktivitas ritual umat Hindu dilandasi oleh adanya keyakinan dan kesadaran bahwa Tuhan (Prajapati/Ida Sanghyang Widhi Wasa) telah menciptakan dan memelihara kehidupan dengan segala berkahnya. Oleh karena itu sebagai makhluk ciptaan-Nya, setiap manusia apalagi umat Hindu hendaknya selalu mengucap puji syukur (angayubagia) yang kemudian dapat merealisasikannya melalui pelaksanaan yadnya dengan segala jenis, bentuk, dan tingkatannya berdasarkan dorongan hati yang tulus ikhlas dan tanpa pamrih.

Kutipan pustaka suci Bhagawadgita, III sloka $12,13,14$ selanjutnya semakin menegaskan sekaligus menguatkan perihal landasan filosofis pelaksanaan aktivitas ritual (yadnya), yaitu :

"Ishtan bhogan hi wo dewa, donsyante yajna bhawitah, tair dattan apradayabho, yobhunkte stena eca sah"

\section{Maknanya :}

'Sesungguhnya keinginan untuk mendapat kesenangan telah diberikan kepadamu oleh Dewa-Dewa karena yadnyamu, sedangkan ia yang telah memperoleh kesenangan tanpa memberi yadnya adalah pencuri' (Pudja, 1981: 78)

"Yajna sisyah sinah santo, nucyanta sarwa kilbisaih, bhujate tuagham papa, ye pacauty atma karanat"

\section{Maknanya :}

'Ia yang memakan sisa yadnya akan terlepas dari segala dosa (tetapi) Ia yang hanya memasak makanan hanya bagi diri sendiri sesungguhnya makan dosa' (Pudja, 1981: 73).

\section{"Annad bhawati bhutani} parjanyad annasam bhawah yajnad bhawati parjanyo yajnah karma samudbhawah"

\section{Maknanya :}

'Adanya makhluk hidup karena makanan, adanya makanan karena hujan, adanya hujan karena yadnya, dan adanya yadnya karena karma' (Pudja, 1981 : 79).

Intisari dari kutipan beberapa teks kitab/ pustaka suci di atas memberikan pemahaman filosofi bahwa hukum mayadnya itu bersifat resiprokal atau timbal balik. Artinya, Tuhan telah menciptakan dunia beserta segala anugrah kehidupan adalah untuk disadari oleh umat manusia, dalam hal ini umat Hindu untuk sepatutnya juga "membalas" dengan cara mayadnya juga. Tujuannya adalah untuk saling memelihara, merawat dan menjaga satu sama lain, sehingga kehidupan ini dapat terus berlangsung, baik di dunia ini maupun di kehidupan nanti. Jika tidak melakukan yadnya dan hanya menikmati saja apa yang sudah dianugrahkan Tuhan, sesungguhnya orang itu adalah pencuri dan akan semakin banyak memakan dosanya sendiri.

Oleh karena itu Hindu mengajarkan umatnya untuk saling menjaga, merawat atau memelihara melalui yadnya, sebagai jalan untuk mencapai kesejahteraan (lahir) dan kebahagiaan tertinggi (batin). Penegasan ini telah disuratkan di dalam kitab Bhagawadgita, III.11 :

"Dewam bhawayata 'nena

Te dewa bhawayantu wah

Parasparam bhayayantah

Sreyah param awapsyatha"

\section{Maknanya :}

'Dengan ini kamu memelihara para dewa, dan dengan ini pula para dewa memelihara dirimu. Jadi dengan saling memelihara satu sama lain, Kamu akan mencapai kebahagiaan yang maha tinggi' (Pudja, 1981: 77).

Jadi perihal mayadnya ini berlaku prinsip timbal balik. Jangankan dengan antar sesama manusia, kehadapan para Dewa sinar suci Tuhanpun berlaku juga hukum mayadnya, yang berguna untuk saling memelihara demi keberlangsungan kehidupan.

\subsection{Kualitas Yadnya}

Mekipun melaksanakan yadnya itu merupakan kewajiban, namun dalam 
pelaksanaannya tetap wajib memperhatikan segi kualitasnya, tidak sekedar kuantitas. Sebab kualitas yadnya akan menentukan apakah aktivitas ritual yadnya itu akan bisa mencapai tujuan (sidhaning don) atau hanya berada pada tahap selesai dilaksanakan (sidhakarya). Menyangkut kualitas yadnya ini, kitab Bhagavadgita, XVII, 11, 12 dan 13 menguraikan adanya tiga (3) tingkatan yadnya yaitu :

"Aphalakanksibhir yajno

widhi-disto ya ijyate

yastawyam eweti manah

samadhaya sa sattwikah"

\section{Maknanya :}

'Yadnya yang dipersembahkan sesuai dengan aturan kitab suci oleh mereka yang tidak mengharapkan ganjaran dan sangat percaya bahwa itu merupakan kewajiban yang harus dilakukan, merupakan yadnya sattwika' (Pudja, 1981: 364).

"Abhisandhaya tu phalam

dambhartham api caiwa yat

ijyate bharata-srestha

tam yajnam widdhi rajas am"

\section{Maknanya :}

'Tetapi, yang dipersembahkan dengan mengharapkan ganjaran atau hanya untuk pamer saja, ketahuilah, wahai Bharatasrestha (Arjuna), bahwa yadnya itu bersifat rajasasika' (Pudja, 1981: 365).

"Widhi-hinam asrstannam mantra-hinam adaksinam shraddha-wirahitam yajnam tamasam paricakshate"

\section{Maknanya :}

'Yadnya yang tidak mengikuti aturan, di mana tak ada makanan yang dibagikan, tak ada mantra diucapkan dan tanpa pemberian amal sedekah dan tanpa keyakinan, dinyatakan sebagai yadnya tamasika' (Pudja, 1981: 365).

Suratan sloka Bhagawadgita di atas, dengan jelas bahkan tegas telah mengelompokkan tingkatan yadnya berdasarkan kualitasnya. Ukuran kualitas, tidak berkaitan dengan unsur besaran kuantitas material tetapi lebih kepada landasan keyakinan serta motif bhakti yang menyertainya. Sehingga jika diringkas, tingkatan kualitas yadnya itu dipilah menjadi tiga (3) tingkatan, yaitu :

1) Tamasika yadnya, yaitu yadnya yang dilaksanakan dengan tidak berdasarkan pada petunjuk sastra atau kitab/pustaka suci, bahkan tanpa mantra, tidak ada kidung suci, tanpa ada daksina, dan tanpa dilandasi kepercayaan/keyakinan.

2) Rajasika yadnya, yaitu yadnya yang dilakukan dengan pamrih, penuh harapan akan hasilnya dan dilakukan untuk maksud pamer atau prestise.

3) Satwika yadnya, yaitu yadnya yang dilakukan sesuai dengan petunjuk kitab/ pustaka suci, serta tanpa mengharapkan pahala, dan percaya sepenuhnya bahwa yadnya yang dilakukan merupakan kewajiban utama dan mulia (Maswinara, 1997 : 469-470).

Merujuk paparan di atas, ternyata tidak mudah untuk melaksanakan ritual berdasarkan konsep Satwika yadnya. Sebab dalam konteks kekinian, pada kenyataannya memang tidak dapat dimungkiri bahwa aktivitas ritual yadnya yang dilaksanakan umat Hindu pada umumnya masih masuk katagori Rajasika yadnya. Sehingga dari segi tingkatan bhaktinya ditempatkan pada level Aparabhakti. Artinya pelaksanaan ritual yadnyanya masih diliputi motif aktualisasi diri yang ditampilkan melalui hasrat unjuk pamer kemampuan. Sehingga pada moment-moment beraktivitas ritual yadnya ada kecenderungan umat untuk berusaha menampilkan yang terbaik, baik secara personal fisikal dengan muatan material yang sarat artifisial, maupun dalam hal persembahan ritual bebantennya. Intinya, penampilan personal dan haturan ritual dianggap lebih penting daripada pendalaman dan peningkatan kesadaran spiritual. Bentuk luar (kemasan) masih dianggap lebih penting daripada substansi (nilai) dan esensi (makna). Penampilan luar (material ritual) dinilai lebih berharga dari pada pendalaman dan atau 
peningkatan spiritual (Widana, 2015: 132).

\section{PENUTUP}

Berpijak pada paparan di atas, aktivitas ritual yadnya yang dilaksanakan umat Hindu dalam konteks kekinian terkesan bersifat formal, berlangsung seperti acara seremonial, bergaya festival, ala karnaval bahkan tidak jarang bergaya kolosal yang bisa saja berbiaya mahal. Konsep filosofi ritual yadnya yang seharusnya menuju satwika yadnya justru terjerumus ke dalam praktik rajasika/tamasika yadnya. Sehingga aktivitas ritual tersebut dapat dikatakan keluar dari petunjuk ajaran, karena masih melekat pamrih untuk mendapat sesuatu yang bersifat duniawi, mulai dari berkah hingga sekedar aktualisasi diri, dengan motif pamer, atau unjuk gengsi (prestise). Akibatnya niat kontemplasi melalui ritual terkalahkan oleh hasrat berkontestasi bergaya selebrasi dalam kemasan komodifikasi masa kini. Harapan untuk merealisasikan konsep filosofi ritual yadnya sebagai jalan pendakian spiritual pun akhirnya terjungkal di tataran ego individual umat yang masih dikuasai ahamkara, sehingga tidak berkemampuan untuk mencapai omkara, sebagai obsesi tertinggi ajaran mayadnya.

\section{DAFTAR PUSTAKA}

Cudamani. 1993. Pengantar Agama Hindu. Jakarta: Hanuman Sakti.

Maswinara, I Wayan. 1997. Dewa-Dewi Hindu. Surabaya : Paramita

Pudja, G dan Tjokorda Rai Sudharta. 1977/1978. Manawadharmasastra

(Manusmrti). Jakarta : Departemen Agama RI.

Pudja, G. 1981. Bhagawadgita (Pancama Weda). Jakarta: Mayasaari.

Putra, I Gusti Agung Mas. 1982. "Upakara Yadnya" Denpasar: Kayu Mas.

Subagiasta, I Ketut. 2006a. Teologi, Filsafat, Etika Dan Ritual. Surabaya: Paramita.

Titib, I Made. 2003. Sinergi Agama-Agama Dan Kebudayaan Dalam Masyarakat Bali. Denpasar : TPr.

Widana, I Gusti Ketut. 2015. Banten Siap Saji Pentas Konsumerisme di Panggung Ritual. Denpasar: Pustaka Bali Post. 